\title{
Phage biocontrol of enteropathogenic and shiga toxin-producing Escherichia coli in meat products
}

\author{
David Tomat ${ }^{1 *}$, Leonel Migliore ${ }^{1}$, Virginia Aquili $^{1}$, Andrea Quiberoni ${ }^{2}$ and Claudia Balagué ${ }^{1}$ \\ Área de Bacteriología, Facultad de Ciencias Bioquímicas y Farmacéuticas, Universidad Nacional de Rosario, Rosario, Argentina \\ ${ }^{2}$ Facultad de Ingeniería Química, Instituto de Lactología Industrial (UNL - CONICET), Santa Fe, Argentina
}

\author{
Edited by: \\ Nora L. Padola, Universidad Nacional \\ del Centro de la Provincia de \\ Buenos Aires, Argentina \\ Reviewed by: \\ Mohamed H. Abdulla, Cochin \\ University of Science and \\ Technology, India \\ Adriana Bentancor, Universidad de \\ Buenos Aires, Argentina \\ *Correspondence: \\ David Tomat, Área de Bacteriología, \\ Facultad de Ciencias Bioquímicas y \\ Farmacéuticas, Universidad \\ Nacional de Rosario, Suipacha 531, \\ S2002LRK Rosario, Santa Fe, \\ Argentina \\ e-mail: dtomat@fbioyf.unr.edu.ar
}

Ten bacteriophages were isolated from faeces and their lytic effects assayed on 103 pathogenic and non-pathogenic Enterobacteriaceae. Two phages (DT1 and DT6) were selected based on their host ranges, and their lytic effects on pathogenic E. coli strains inoculated on pieces of beef were determined. We evaluated the reductions of viable cells of Escherichia coli O157:H7 and non-O157 Shiga toxigenic E. coli strains on meat after exposure to DT6 at 5 and $24^{\circ} \mathrm{C}$ for 3,6 , and $24 \mathrm{~h}$ and the effect of both phages against an enteropathogenic E. coli strain. Significant viable cell reductions, compared to controls without phages, at both temperatures were observed, with the greatest decrease taking place within the first hours of the assays. Reductions were also influenced by phage concentration, being the highest concentrations, $1.7 \times 10^{10}$ plaque forming units per milliliter (PFU/mL) for DT1 and $1.4 \times 10^{10} \mathrm{PFU} / \mathrm{mL}$ for DT6, the most effective. When enteropathogenic E. coli and Shiga toxigenic E. coli $(\mathrm{O} 157: \mathrm{H} 7)$ strains were tested, we obtained viable cell reductions of $0.67 \log (p=0.01)$ and $0.77 \log (p=0.01)$ after $3 \mathrm{~h}$ incubation and $0.80 \log (p=0.01)$ and $1.15 \log (p=0.001)$ after $6 \mathrm{~h}$. In contrast, all nonpathogenic $E$. coli strains as well as other enterobacteria tested were resistant. In addition, phage cocktail was evaluated on two strains and further reductions were observed. However, E. coli bacteriophage insensitive mutants (BIMs) emerged in meat assays. BIMs isolated from meat along with those isolated by using the secondary culture method were tested to evaluate resistance phenotype stability and reversion. They presented low emergence frequencies $\left(6.5 \times 10^{-7}-1.8 \times 10^{-6}\right)$ and variable stability and reversion. Results indicate that isolated phages were stable on storage, negative for all the virulence factors assayed, presented lytic activity for different $E$. coli virotypes and could be useful in reducing Shiga toxigenic E. coli and enteropathogenic E. coli viable cells in meat products.

Keywords: Escherichia coli, bacteriophage, phage biocontrol, bacteriophage insensitive mutant, phage cocktail

\section{INTRODUCTION}

Shiga toxin-producing Escherichia coli (STEC) are human pathogens that can cause diarrhea, as well as severe clinical manifestations including hemorrhagic enterocolitis, hemolytic uremic syndrome (HUS), and thrombotic thrombocytopenic purpura (Su and Brandt, 1995; Griffin et al., 2002; Yoon and Hovde, 2008). STEC produce several virulence factors which contribute to their pathogenicity. Shiga toxins (Stx), AB type toxins that inhibit protein synthesis in target cells, are the most characterized virulence factors (Thorpe et al., 2002). Shiga toxins produced in the intestines by STEC are able to enter the systemic circulation causing severe damage to distal organs. The degree of damage is related to the amount of toxin produced during the infection (Ritchie et al., 2003). STEC synthesize two main types of Shiga toxins encoded by stx 1 and $s t x 2$ genes. Moreover, the enterocyte attaching-and-effacing lesion gene (eaeA), which is also present in enteropathogenic strains (EPEC), can contribute to the virulence of STEC. The gene codes for the intimin protein, which allows bacteria to attach themselves to the intestinal epithelium (Frankel et al., 1998).
Foodborne disease-producing Enterobacteriaceae, such as Shigella spp., Salmonella spp., EPEC and STEC, are important etiologic agents of infantile gastroenteritis in Argentina (Binsztein et al., 1999; Rivas et al., 2008). In developing countries, EPEC are the cause of outbreaks of infantile diarrhea with high mortality in children under two years of age. In Argentina, HUS is endemic, with approximately 400 new cases being reported annually by National Health Surveillance System (Rivas et al., 2006), and more than 7000 cases being reported since 1965 (NCASP, 1995). In 2005 , the annual incidence of HUS is 13.9 cases/100,000 children under five years of age (Rivas et al., 2006). Recent epidemiological studies showed that there is a sustained global increase in the isolation of non-O157 STEC strains from humans (Tozzi et al., 2003; Brooks et al., 2005; Bettelheim, 2007) and animals (Jenkins et al., 2003; Fernandez et al., 2009), particularly STEC of serogroups O26, O103, and O111 (Ogura et al., 2007).

The therapeutic potential of bacteriophages has been explored since they were discovered by Felix d'Herelle (Summers, 1999). Some of the attributes that make bacteriophages interesting as tools for biological control are: (i) their ability to infect and lyse 
specific bacterial target cells and their inability to infect eukaryotic cells; (ii) phages generally do not cross bacterial species or genus barriers, and therefore do not affect desirable microorganisms commonly present in foods, the gastrointestinal tract or the normal bacterial microbiota (Carlton et al., 2005); (iii) phages need a bacterial host in which to multiply and therefore will persist only as long as the sensitive host is present (Clark and March, 2006). The potential of bacteriophages to control food pathogens is reflected in recent studies involving various pathogens including Campylobacter jejuni (Atterbury et al., 2003; Bigwood et al., 2008), E. coli O157:H7 (O'Flynn et al., 2004; Abuladze et al., 2008) and Listeria monocytogenes (Leverentz et al., 2003; Guenther et al., 2009; Holck and Berg, 2009). Several strategies are currently being applied to preserve perishable refrigerated foods and extend their shelf-life. However, physical processes and chemical compounds (preservatives) used for this purpose may alter meat organoleptic properties. Although bacteriophages represent a novel approach, there are no reports of their industrial use to improve safety, even if this "new, ecological, and specific" technology may be cheaper than "older" technologies, since phages can be isolated from the environment and are self-replicating entities. On the other hand, their inclusion into a meat product can be seen as a less aggressive approach.

The aim of this work was to isolate phages with specific lytic capacity for $E$. coli strains in order to determine phage host range and analyze their potential as biocontrol agents for STEC and EPEC strains in beef products.

\section{MATERIALS AND METHODS \\ BACTERIOPHAGE ISOLATION AND PREPARATION OF STOCKS}

E. coli $\mathrm{DH} 5 \alpha$ was used to isolate bacteriophages from fifty stool samples of patients with diarrhea treated at the Centenary Hospital, Rosario. This strain was grown up to an optical absorbance of $1\left(\mathrm{~A}_{600}=1\right)$ in $10 \mathrm{~mL}$ of Hershey broth $(8 \mathrm{~g} / \mathrm{L}$ Bacto nutrient broth, $5 \mathrm{~g} / \mathrm{L}$ Bacto peptone, $5 \mathrm{~g} / \mathrm{L} \mathrm{NaCl}$, and $1 \mathrm{~g} / \mathrm{L}$ glucose) (Difco, Detroit, MI, USA) supplemented with $\mathrm{MgSO}_{4}$ (5 mM) (Cicarelli, San Lorenzo, Santa Fe, Argentina). A portion of faeces $(5 \mathrm{~g})$ was added and the culture was incubated for a further $12 \mathrm{~h}$ at $37^{\circ} \mathrm{C}$. Next, chloroform $(0.5 \mathrm{~mL}$, Cicarelli) was added and the preparation was mixed and centrifuged at $15,000 \times \mathrm{g}$ for $10 \mathrm{~min}$. The supernatant was then filtered through a $0.45 \mu \mathrm{m}$ pore size (Gamafil S.A., Buenos Aires, Argentina) (Kudva et al., 1999). Bacteriophage isolation and purification were performed by the double-layer plaque technique (Balagué et al., 2006). Briefly, aliquots of filtrates (10 and $100 \mu \mathrm{L})$ were mixed with $100 \mu \mathrm{L}$ of recipient strain culture $\left(\mathrm{A}_{600}=1\right)$, three $\mathrm{mL}$ of molten soft agar at $45^{\circ} \mathrm{C}$ (Hershey broth supplemented with $5 \mathrm{mM} \mathrm{MgSO}_{4}$ and $0.7 \%$ agar) were added to each suspension and the mixture was poured onto pre-solidified Hershey agar plates and incubated overnight at $37^{\circ} \mathrm{C}$. To isolate and purify phages, well-defined single plaques on the soft agar were picked and placed in $5 \mathrm{~mL}$ of Hershey medium supplemented with $5 \mathrm{mM}$ $\mathrm{MgSO}_{4}$. Tubes were kept at $4^{\circ} \mathrm{C}$ for $2 \mathrm{~h}$ and then inoculated with $100 \mu \mathrm{L}$ of recipient strain culture $\left(\mathrm{A}_{600}=1\right)$. Inoculated tubes were incubated at $37^{\circ} \mathrm{C}$ with intermittent shaking until complete lysis. Next, chloroform $(0.1 \mathrm{~mL})$ was added and cultures were centrifuged at $4000 \times \mathrm{g}$ for $10 \mathrm{~min}$. Phage stocks were stored at $4^{\circ} \mathrm{C}$ and enumerated by the double-layer plaque technique (Jamalludeen et al., 2007). These steps were repeated three times. Stability of phage stocks was evaluated after two months of storage at $4^{\circ} \mathrm{C}$.

\section{BACTERIOPHAGE AND BACTERIA CHARACTERIZATION}

Phage electron micrographs were obtained by the procedure of Bolondi et al. (1995). Phage suspensions were concentrated by centrifugation $\left(1 \mathrm{~h}, 70,000 \times \mathrm{g}, 5^{\circ} \mathrm{C}\right)$ and subsequently stained with phosphotungstic acid (2\% w/v) (Biopack, Buenos Aires, Argentina). Electron micrographs were obtained using a JEOL 1200 EX II electron microscope (INTA Castelar, Buenos Aires, Argentina) operating at $85 \mathrm{kV}$. Phage morphologies and dimensions (head diameter, tail length, and diameter) were recorded.

Phages and strains of $E$. coli were tested for the presence of toxin-encoding genes (stx1, Shiga toxin 1; stx2, Shiga toxin 2; eaeA, attaching-and effacing; LT1, thermolabile toxin and ST1, thermostable toxin) of diarrheogenic E. coli by the polymerase chain reaction (PCR) using primers detailed in Table 1 (Pass et al., 2000). PCR conditions were as follows: initial denaturing step at $95^{\circ} \mathrm{C}$ for $2 \mathrm{~min}$, followed by 25 cycles of $95^{\circ} \mathrm{C}$ for $30 \mathrm{~s}$, annealing at $63^{\circ} \mathrm{C}$ for $30 \mathrm{~s}$ and elongation at $72^{\circ} \mathrm{C}$ for $30 \mathrm{~s}$, followed by a final step at $72^{\circ} \mathrm{C}$ for $5 \mathrm{~min}$ to achieve complete product elongation. E. coli ATCC43889 (stx2 and eaeA), ATCC43890 (stx1), and ATCC43895 (stx1, stx2, and eaeA, and also harboring the stx2 phage, 933W) were used as positive controls, while enterotoxigenic E. coli ATCC35401 was used for LT1 and ST1 genes. E. coli HB101 and ATCC98222 were utilized as negative controls. Amplified products were resolved by electrophoresis using 3\% agarose gels in TBE buffer ( $89 \mathrm{mM}$ Tris borate, $2 \mathrm{mM}$ EDTA, $\mathrm{pH}$ 8.0) (Promega, Madison, WI, USA) at $100 \mathrm{~V}$ for $3 \mathrm{~h}$. Gels were stained with ethidium bromide $(0.5 \mu \mathrm{g} / \mathrm{mL})$ (Sigma, St. Louis, MO, USA) and PCR products were visualized under UV light.

\section{BACTERIOPHAGE SPECIFICITY}

The host range of each phage was determined by the double layer agar technique using 44 strains isolated from stool

\begin{tabular}{lll}
\hline \multicolumn{2}{l}{ Table $\mathbf{1}$ | Sequences of primers used in this study. } \\
\hline Gene & Primer $^{\mathbf{a}}$ & $\begin{array}{l}\text { Product size } \\
\text { (bp) expected }\end{array}$ \\
\hline stx1 & $\begin{array}{l}\text { fp: 5'-ACGTTACAGCGTGTTGCRGGGATC-3' } \\
\text { bp: 5'-TTGCCACAGACTGCGTCAGTRAGG-3' }\end{array}$ & 121 \\
stx2 & $\begin{array}{l}\text { fp: 5'-TGTGGCTGGGTTCGTTTATACGGC-3' } \\
\text { bp: 5'-TCCGTTGTCATGGAAACCGTTGTC-3' }\end{array}$ & 102 \\
eaeA & $\begin{array}{l}\text { fp: 5'-TGAGCGGCTGGCATGATGCATAC-3' } \\
\text { bp: 5'-TCGATCCCCATCGTCACCAGAGG-3' }\end{array}$ & 241 \\
LT1 & $\begin{array}{l}\text { fp: 5'-TGGATTCATCATGCACCACAAGG-3' } \\
\text { bp: 5'-CCATTTCTCTTTTGCCTGCCATC-3' }\end{array}$ & 360 \\
ST1 & fp: 5'-TTTCCCCTCTTTTAGTCAGTCAACTG-3' & 160 \\
& bp: 5'-GGCAGGACTACAACAAAGTTCACAG-3' & \\
\hline
\end{tabular}

${ }^{a} f p$, forward primer; bp, backward primer. stxl and stx2: Shiga toxin 1 and 2 encoding genes; eaeA: intimin encoding gene; LTI and STI: thermolabile and thermostable toxins encoding genes. 
samples, and urine cultures (uropathogenic E. coli, UPEC). Stool and urine samples were streaked in Cystine Lactose Electrolyte Deficient (CLED) agar plates. Simmons citrate agar test was performed on growing lactose positive colonies. After incubation for $24 \mathrm{~h}$ at $35^{\circ} \mathrm{C}$, only lactose positive and citrate negative colonies were further identified using API system (Biomerieux, Bs. As., Argentina). Sixteen E. coli strain from food (Balagué et al., 2006), one uropathogenic E. coli strain (E. coli T149) which expresses fimbriae $\mathrm{P}$ and $\alpha$-hemolysin (Balagué et al., 2004) and five ATCC E. coli strains were also tested (ATCC 43890; 43889; 43895; 35401 and 98222). Previously characterized (API system) isolates from stool samples were also tested: Shigella flexneri, S. sonnei, Proteus mirabilis, Citrobacter freundii, Klebsiella pneumoniae, Salmonella enteritidis, Salmonella Typhi and Salmonella Typhimurium. Strains tested against stock phages are listed in Table 2 . Bacteriophage sensitivity was assayed by placing $10 \mu \mathrm{L}$ of phage suspension on the solidified soft-agar layer inoculated with $100 \mu \mathrm{L}$ of each bacterial culture, incubated for $24 \mathrm{~h}$ at $37^{\circ} \mathrm{C}$, and the presence of lysis zones or plaques was examined (Goodridge et al., 2003).

\section{MEAT ASSAYS}

Beef from cow hindquarter purchased from retail was aseptically cut into pieces $\left(1 \mathrm{~cm}^{2}\right.$ of surface and $0.4 \mathrm{~cm}$ thick), placed in petri dishes and pre-equilibrated to 5 or $24^{\circ} \mathrm{C}$. The required $\mathrm{pH}$ was obtained by washing with sodium chloride-magnesium sulfate (SM) buffer (0.05 M TRIS, $0.1 \mathrm{M} \mathrm{NaCl}, 0.008 \mathrm{M} \mathrm{MgSO}_{4}$, $0.01 \% \mathrm{w} / \mathrm{v}$ gelatin, $\mathrm{pH}=7.5)$ prior to inoculation with bacteria and phage. Host strains employed in this study, namely nonO157 STEC (ARG4827; serogroup O18; harboring stx1 and stx2 genes) (Balagué et al., 2006), O157:H7 STEC (464; harboring stx1 and eaeA genes) and an EPEC (EPEC920; which harbors

Table 2 | Strains tested against stock phages.

\begin{tabular}{lll}
\hline Source & Strains (amount) & $\begin{array}{l}\text { Strains characteristics/ } \\
\text { description }\end{array}$ \\
\hline Food & Escherichia coli (10) & $\begin{array}{l}8 \text { non-O157 STEC and } \\
2 \text { O157:H7 STEC }\end{array}$ \\
\hline Stool sample & Escherichia coli (9) & $\begin{array}{l}4 \text { O157:H7 STEC and } \\
5 \text { EPEC }\end{array}$ \\
& Escherichia coli (18) & Non-pathogenic \\
\cline { 2 - 3 } & Shigella spp. & Other enterobacteria \\
& Salmonella spp. & \\
& Proteus mirabilis & \\
& Citrobacter freundii & \\
& Klebsiella pneumoniae (17) & \\
\hline Urine culture & Escherichia coli (17) & UPEC \\
\hline ATCC & Escherichia coli (5) & $35401 ; 43889 ; 43890 ;$ \\
& & 43895 and 98222
\end{tabular}

EPEC, enteropathogenic E. coli; O157:H7 STEC, O157:H7 Shigatoxigenic E. coli; non-O157 STEC, Shigatoxigenic non-O157 E. coli; UPEC, urophatogenic E. coli; ATCC, american type culture collection.
eaeA gene), were grown in Hershey medium supplemented with $\mathrm{MgSO}_{4}(5 \mathrm{mM})$ for $12 \mathrm{~h}$ at $37^{\circ} \mathrm{C}$. Bacterial strains and specific bacteriophages added to the meat samples are detailed in Table 3. Twenty $\mu \mathrm{L}$ of each diluted bacterial suspension (ranging from $5.9 \times 10^{5}$ to $3.9 \times 10^{7} \mathrm{CFU} / \mathrm{mL}$ ) were pipetted onto the surface of each meat piece and allowed to attach for $10 \mathrm{~min}$ at room temperature. Another $20 \mu \mathrm{L}$ of each bacteriophage were then pipetted on the meat, at low multiplicity of infection (MOI), $1.7 \times 10^{9} \mathrm{PFU} / \mathrm{mL}$ for DT1 and $1.4 \times 10^{9} \mathrm{PFU} / \mathrm{mL}$ for DT6, or high MOI, $1.7 \times 10^{10} \mathrm{PFU} / \mathrm{mL}$ for DT1 and $1.4 \times 10^{10} \mathrm{PFU} / \mathrm{mL}$ for DT6. Pieces of meat were also added with SM buffer $(\mathrm{pH}$ 7.5), instead of phage suspension, as controls. At 3, 6, and $24 \mathrm{~h}$, meat pieces were transferred to a sterile bag, $5 \mathrm{~mL}$ SM buffer were added and samples processed for $2 \mathrm{~min}$ in a Stomacher (Seward, London, UK). A $1 \mathrm{~mL}$ portion of the stomacher fluid was transferred to a sterile tube and cells were pelleted by centrifugation at $3000 \times g$ for $10 \mathrm{~min}$. The supernatant was removed and cells were resuspended in $1 \mathrm{~mL}$ SM buffer. Finally, a $0.1 \mathrm{~mL}$ sample was removed, serially diluted $\left(10^{2}-10^{4}\right.$-fold) in SM buffer and $0.1 \mathrm{~mL}$ volumes of each dilution were plated on Hershey agar for viable cell enumeration (Bigwood et al., 2008). Phage cocktail (DT1 and DT6 in equal proportions) was assayed on E. coli $\mathrm{DH} 5 \alpha$ (indicator strain used for phage isolation) and in $\mathrm{O} 157: \mathrm{H} 7$ STEC (464) using the methodology employed for each individual phage described above. Three replicates were performed for each treatment and one meat piece processed for replicate. Uninoculated controls were tested to determine the presence of naturally occurring bacteriophages. Plaques $(\mathrm{PFU} / \mathrm{mL})$ were evaluated by the double layer agar technique (Jamalludeen et al., 2007).

\section{BACTERIOPHAGE INSENSITIVE MUTANTS (BIMS) ISOLATION}

Bacteriophage insensitive mutants (BIMs) were isolated by the secondary culture method described by Guglielmotti et al. (2007) with some modifications. E. coli sensitive strains (one EPEC, three O157:H7 STEC and one non-O157 STEC) $\left(\mathrm{A}_{600}=0.2-0.3\right)$ were infected with a phage suspension at different infection ratios (multiplicity of infection, MOI of $\approx 10$ and 1 ), incubated in Hershey broth at $37^{\circ} \mathrm{C}$ for $24 \mathrm{~h}$ and observed visually until complete lysis. An uninfected culture of each E. coli strain was used as a control. Cultures exhibiting complete and delayed lysis were the best candidates to isolate BIMs. After lysis, further incubation for $48 \mathrm{~h}$ at $37^{\circ} \mathrm{C}$ was required for secondary growth. Each tube with secondary growth was spread on Hershey agar plates for colony isolation.

BIMs were isolated from meat as described in meat assays methodology described above modified with an extended incubation time $(48 \mathrm{~h})$ at $37^{\circ} \mathrm{C}$. For both of the aforementioned methodologies, after incubation of agar plates, eight different colonies were randomly isolated (on agar plates) and cultured overnight in Hershey broth at $37^{\circ} \mathrm{C}$. These isolates were purified by three consecutive streakings on Hershey agar plates. The growing colonies were isolated as presumptive BIMs.

\section{BIMs CONFIRMATION}

Presumptive BIMs were confirmed by a liquid culture sensitivity test (Guglielmotti et al., 2007). Briefly, a log-phase culture 
Table 3 | E. coli viable cell logarithmic reductions after phage treatment of contaminated meat products.

\begin{tabular}{|c|c|c|c|c|c|}
\hline \multirow[t]{2}{*}{ Phage stock/sensitive strain } & \multicolumn{2}{|c|}{ Assay conditions } & \multicolumn{3}{|c|}{$\begin{array}{l}\text { Log reduction in } E \text {. coli viable cells }{ }^{a} \\
\text { after the incubation time }(h)^{b}\end{array}$} \\
\hline & $\mathbf{T}\left({ }^{\circ} \mathbf{C}\right)$ & MOI & 3 & 6 & 24 \\
\hline \multirow[t]{3}{*}{ DT1/EPEC (920) } & 5 & $4.4 \times 10^{2}$ & NS & ${ }^{* *} 0.80 \pm 0.14$ & NS \\
\hline & 24 & $4.8 \times 10^{2}$ & $*^{*} 0.30 \pm 0.05$ & NS & NS \\
\hline & 5 & $4.4 \times 10^{1}$ & NS & $* * 0.49 \pm 0.09$ & NS \\
\hline \multirow[t]{4}{*}{ DT6/EPEC (920) } & 5 & $5.2 \times 10^{2}$ & ${ }^{* *} 0.67 \pm 0.12$ & $* * 0.59 \pm 0.11$ & ${ }^{*} 0.46 \pm 0.15$ \\
\hline & 24 & $6.5 \times 10^{3}$ & ${ }^{*} 0.32 \pm 0.09$ & NS & NS \\
\hline & 5 & $5.2 \times 10^{1}$ & NS & ${ }^{*} 0.30 \pm 0.08$ & NS \\
\hline & 24 & $6.5 \times 10^{2}$ & NS & NS & NS \\
\hline DT6/non-O157 STEC (ARG4827) & 5 & $2.4 \times 10^{4}$ & ${ }^{*} 0.33 \pm 0.09$ & ${ }^{*} 0.47 \pm 0.12$ & ${ }^{*} 0.56 \pm 0.17$ \\
\hline \multirow[t]{4}{*}{ DT6/O157:H7 STEC (464) } & 5 & $2.3 \times 10^{3}$ & ${ }^{*} 0.59 \pm 0.16$ & $* * 0.86 \pm 0.15$ & ${ }^{*} 0.38 \pm 0.10$ \\
\hline & 24 & $5.8 \times 10^{3}$ & ${ }^{* *} 0.77 \pm 0.14$ & $* * * 1.15 \pm 0.12$ & NS \\
\hline & 5 & $2.3 \times 10^{2}$ & ${ }^{*} 0.38 \pm 0.09$ & ${ }^{*} 0.62 \pm 0.18$ & NS \\
\hline & 24 & $5.8 \times 10^{2}$ & NS & ${ }^{* *} 0.74 \pm 0.13$ & NS \\
\hline \multirow[t]{2}{*}{ Cocktail/DH5 $\alpha$} & 5 & $2.25 \times 10^{4}$ & ${ }^{*} 0.91 \pm 0.19$ & ${ }^{* *} 2.16 \pm 0.20$ & $* * 2.23 \pm 0.21$ \\
\hline & 24 & $1.75 \times 10^{4}$ & ${ }^{*} 0.66 \pm 0.15$ & NS & NS \\
\hline \multirow[t]{2}{*}{ Cocktail/O157:H7 STEC (464) } & 5 & $1.56 \times 10^{5}$ & NS & NS & NS \\
\hline & 24 & $3.33 \times 10^{5}$ & $* * 1.43 \pm 0.24$ & $* * 2.58 \pm 0.21$ & $* * 2.20 \pm 0.22$ \\
\hline
\end{tabular}

MOI, multiplicity of infection (PFU/CFU); NS, not significant. Mean values of treated and control samples not significantly different using the scheffé method $\left({ }^{*}\right.$ significant at $p=0.05 ;{ }^{* *}$ significant at $p=0.01 ;{ }^{* * *}$ significant at $p=0.001$ ).

${ }^{a}$ Log reduction in E. coli viable cells with respect to phage-free control.

${ }^{b}$ Mean of three data points \pm standard deviations.

$\left(\mathrm{A}_{600}=0.2-0.3\right)$ of each presumptive BIM in Hershey broth was infected with the phage suspension at various MOI $(\approx 10$ and 1). Uninfected cultures of each E. coli strain were used as controls. BIMs cultures were incubated in Hershey broth at $37^{\circ} \mathrm{C}$ until growth of control strains was evident. Infected cultures that did not lyse at the first attempt were subcultured again. Each second subculture was prepared by transferring $2-3 \%$ of the final volume from the first culture to another test tube with $1 \mathrm{~mL}$ of fresh broth. When no bacterial lysis was evident, the resulting culture was stored at $4^{\circ} \mathrm{C}$ and subcultured under the same conditions. Presumptive BIMs that survived the third subculture were considered to be confirmed BIMs. Sensitivity of each parent strain (sensitive) was always determined in parallel to ensure lytic activity of phage suspensions.

\section{DETERMINATION OF BACTERIOPHAGE-INSENSITIVE MUTANT FREOUENCY, REVERSION, AND STABILITY}

The emergence frequency of BIMs was evaluated by mixing the appropriate volume of an overnight culture of each strain (EPEC920 and O157:H7 STEC 464) and phage suspension (DT1 and DT6) to obtain a MOI of 100. The bacterium-phage mixture was supplemented with $\mathrm{MgSO}_{4}(5 \mathrm{mM})$, plated by the double-layer agar technique and incubated overnight at $37^{\circ} \mathrm{C}$. BIM frequency was estimated as the ratio of the number of confirmed BIM to the initial bacterial number. All the experiments were performed in duplicate. Selected BIMs were propagated through 50 generations at $37^{\circ} \mathrm{C}$ and then checked by a plaque assay to evaluate reversion to phage sensitivity (O'Flynn et al., 2004).

Phage resistance stability was assayed by seven sequential subcultures of $2 \%$ portions of BIM cultures (Hershey broth) with independent addition of phage at each subculture (Guglielmotti et al., 2007). The loss of phage resistance was determined by comparing lysis of BIM culture with the control (mutant subculture without phage addition). The subculture where lysis first occurred was recorded.

\section{STATISTICAL ANALYSIS}

Means and standard deviations for data sets were calculated. Differences between means for control (untreated) and treated samples were compared by the Scheffé method and Origin 6.0 for graphics. Differences were considered statistically significant when $p$-values were $<0.05$. 


\section{RESULTS \\ ISOLATION, VIABILITY, AND CHARACTERISTICS OF BACTERIOPHAGE STOCKS}

A total of 10 bacteriophage stocks were obtained from diarrheic stool samples, titred and stored at $4^{\circ} \mathrm{C}$. Figure 1 shows plaques produced by DT1 and DT6 on the EPEC920 and O157:H7 STEC strains. Phage concentration ranged between $1.2 \times 10^{10} \mathrm{PFU} / \mathrm{mL}$ and $4.8 \times 10^{10} \mathrm{PFU} / \mathrm{mL}$. The viability of each bacteriophage stock stored at $4^{\circ} \mathrm{C}$ was evaluated after two months and similar titers were obtained, suggesting that the storage method used was adequate. Electronic microscopy allowed us to infer that bacteriophages DT1 and DT6, could taxonomically belong to T-even type of the Myoviridae family. Phages DT1 and DT6 had icosahedral heads and contractile tails. DT1 dimensions were of $89.3 \mathrm{~nm}$ (head diameter), $127.8 \mathrm{~nm}$ (tail length), $20.8 \mathrm{~nm}$ (tail thickness), and a total length of $217.1 \mathrm{~nm}$; for DT6 measures were of $82.1 \mathrm{~nm}$ (head diameter), $125.7 \mathrm{~nm}$ (tail length), $17.7 \mathrm{~nm}$ (tail thickness), and $207.8 \mathrm{~nm}$ (total length) (Figure 2). PCR determinations of virulence factors (Stx1; Stx2; ST1; LT1 and Intimin) were negative for all bacteriophage stocks.

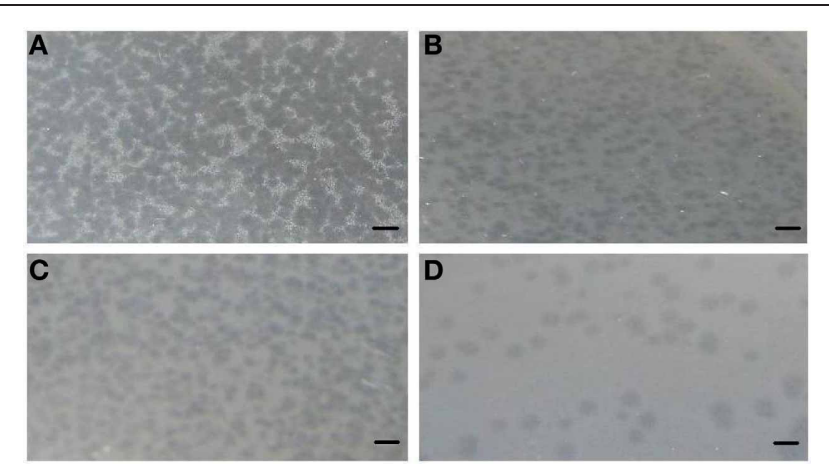

FIGURE 1 | Plaques produced by DT1 and DT6 on EPEC920 (A and B, respectively) and 0157:H7 STEC strains ( $C$ and $D$, respectively). Bars represent $1 \mathrm{~cm}$.

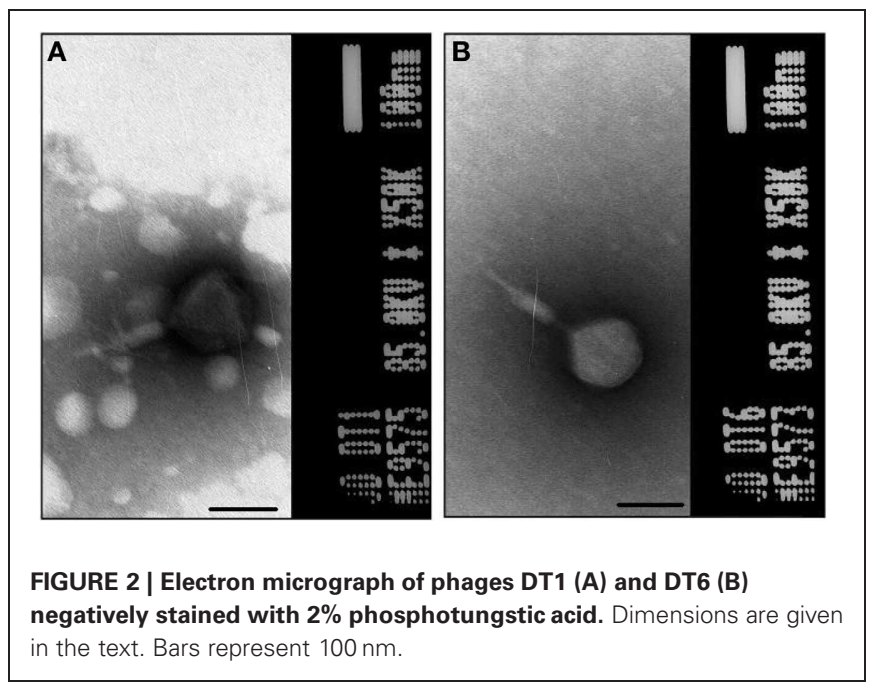

\section{BACTERIOPHAGE SPECIFICITY}

Non-E. coli and non-pathogenic E. coli strains were resistant to the lytic action of phages. Among the pathogenic E. coli, six (6) E. coli O157:H7 STEC, three (3) non-O157 STEC, five (5) EPEC, and two (2) UPEC strains were sensitive to phages evaluated (Table 4).

\section{BIOCONTROL TESTS ON MEAT PRODUCTS}

Two bacteriophages, which formed clearly defined plaques, with different host range were selected. The phage with the narrower range (DT1) was tested on an EPEC strain while the phage with the broader range (DT6) was tested on the same EPEC strain assayed previously and two STEC strains, one O157:H7 and one non-O157.

Significant decreases $(p=0.05)$ in viable cells $(\mathrm{VC})$ for all tested strains were observed in comparison to the phage-free controls. Table 3 shows log VC significant reductions $(p<0.05)$ at high MOI in EPEC920, non-O157 STEC and O157:H7 STEC strain/DT6 systems after 3-h incubation, and in all phage/strain systems after 6 -h incubation at $5^{\circ} \mathrm{C}$. At high MOI values, VC reduction were still significant $(p=0.05)$ after $24 \mathrm{~h}$ of DT6 phage exposure. When the test was carried out at $24^{\circ} \mathrm{C}$, significant VC reduction $(p<0.05)$ were observed after $3 \mathrm{~h}$ for DT1/EPEC920, DT6/O157:H7 STEC, DT6/EPEC920, and DT6/non-O157 STEC. These reductions were not maintained after 6 or $24 \mathrm{~h}$, with the exception of the $1.15 \mathrm{log}$ reduction obtained for DT6/O157:H7 STEC after $6 \mathrm{~h}$.

When the results obtained with different MOIs were compared, significant differences $(p=0.05)$ at both temperatures were observed for most phages/bacterium combinations. Reductions in a phage/bacterium system were higher at the highest temperature, up to $0.29 \log (1.15 \log -0.86 \log ) \mathrm{CFU}$ for

Table 4 | Host range of stock phages.

\begin{tabular}{|c|c|c|}
\hline Phage stock & E. coli sensitive strains & $\begin{array}{l}\text { Total sensitive } \\
\text { strains }\end{array}$ \\
\hline DT1 & $\begin{array}{l}2 \text { EPEC; } 1 \text { O157:H7 STEC; } \\
1 \text { non-O157 STEC }\end{array}$ & 4 \\
\hline DT2 & 2 EPEC; 3 O157:H7 STEC & 5 \\
\hline DT3 & $\begin{array}{l}4 \text { EPEC; } 6 \text { O157:H7 STEC; } \\
3 \text { non-O157 STEC }\end{array}$ & 13 \\
\hline DT4 & $\begin{array}{l}4 \text { EPEC; } 5 \text { O157:H7 STEC; } \\
3 \text { non-O157 STEC }\end{array}$ & 12 \\
\hline DT5 & 2 EPEC; 3 O157:H7 STEC & 5 \\
\hline DT6 & $\begin{array}{l}4 \text { EPEC; } 6 \text { O157:H7 STEC; } \\
3 \text { non-O157 STEC }\end{array}$ & 13 \\
\hline LM1 & $\begin{array}{l}2 \text { EPEC; } 4 \text { O157:H7 STEC; } \\
1 \text { non-0157 STEC }\end{array}$ & 7 \\
\hline LM2 & $\begin{array}{l}1 \text { EPEC; } 1 \text { O157:H7 STEC; } \\
2 \text { non-O157 STEC }\end{array}$ & 4 \\
\hline LM3 & $\begin{array}{l}2 \text { EPEC; } 3 \text { O157:H7 STEC; } \\
2 \text { non-O157 STEC; } 1 \text { UPEC }\end{array}$ & 8 \\
\hline LM4 & $\begin{array}{l}1 \text { EPEC; } 2 \text { O157:H7 STEC; } \\
2 \text { non-O157 STEC; } 1 \text { UPEC }\end{array}$ & 6 \\
\hline
\end{tabular}

EPEC, enteropathogenic E. coli; 0157:H7 STEC, O157:H7 Shigatoxigenic E. coli; non-O157 STEC, Shigatoxigenic non-O157 E. coli; UPEC, uropathogenic E. coli. 
DT6/O157:H7 STEC at $6 \mathrm{~h}$, with exception in a single case for the DT6/EPEC920 system, after 3-h incubation.

Phage stocks displayed different host range (Table 4), some having limited and others having a broader range. The lytic ability of phages at different MOI values and temperatures is shown in Figure 3. The biocontrol effectiveness against EPEC920 shown by DT1 (Figures 3A,B) and DT6 (Figures 3C,D) phages was different only at the lower temperature. At $5^{\circ} \mathrm{C}$, DT1 produced a greater reduction in the number of $\mathrm{VC}$ after 6-h incubation than DT6, but DT6 biocontrol over EPEC920 was faster and prolonged. At $24^{\circ} \mathrm{C}$ there was no difference in the lytic effects of phages with the exception at the longer incubation time and lower MOI $\left(4.8 \times 10^{1} \mathrm{PFU} / \mathrm{CFU}\right)$ where DT1 was more effective. DT6 was also active against O157:H7 strains; being more effective at $24^{\circ} \mathrm{C}$ (Figure 3F) though with a prolonged lytic action at $5^{\circ} \mathrm{C}$ (Figure 3E).

The phage cocktail successfully reduced DH $5 \alpha \mathrm{VC}$ only at $5^{\circ} \mathrm{C}$, while for O157:H7 STEC reductions took place only at $24^{\circ} \mathrm{C}$ (Figure 4). DH5 $\alpha$ was significantly reduced at 3,6 , and $24 \mathrm{~h}$, being $2.23 \log$ the major reduction value obtained at $24 \mathrm{~h}$. For O157:H7 STEC, VC reductions up to $2.58 \log$ at $6 \mathrm{~h}$ were observed, in addition, phage cocktail was able to achieve an effective and prolonged biocontrol effect (2.20 log at $24 \mathrm{~h}$ ) (Table 3).

\section{ISOLATION AND REVERSION OF BIMs}

After incubating meat inoculated with phage/bacteria systems at $24^{\circ} \mathrm{C}$ for $24 \mathrm{~h}$, significant bacterial growth was observed. To assess whether bacterial re-growth on meat experiments may be due to resistance, eight (8) potential BIMs were isolated from meat incubated for $48 \mathrm{~h}$ at $37^{\circ} \mathrm{C}$ and only $2(25 \%)$ were confirmed as BIMs by the liquid culture sensitivity test method. Another eight (8) presumptive BIMs were isolated by the secondary culture method and $6(75 \%)$ were confirmed. BIM frequencies observed for all the evaluated strains were low, ranging from $6.5 \times 10^{-7}$ to $1.8 \times 10^{-6}$ (Table 5).

One BIM, which could form a lawn, was found to be susceptible to phage DT6. BIMs evaluated for phage DT1 were resistant and showed no reversion to phage sensitivity. Mutants isolated from EPEC920 maintained their phenotype up to the fifth subculture. Mutants isolated from O157:H7 STEC maintained resistance up to the fourth subculture and only one was resistant at the seventh subculture.

\section{DISCUSSION}

Biocontrol by bacteriophages in meat products was developed in the last years and their recent "generally recognized as safe" (GRAS) designation and approval as food additives (FDA, 2006) has opened the discussion about "edible virus." Phages are naturally present in significant numbers in water and food (Sulakvelidze, 2011). In fresh meats and meat products more than $10^{8}$ viable bacteriophages per gram may be present (Kennedy and Bitton, 1987), implying that phages are commonly consumed in large numbers. In addition, bacteriophages are especially abundant in the gastrointestinal tract (Breitbart et al., 2003; Hitch et al., 2004). However, most phage-host systems are highly specific, which is a general limitation (Carlton et al., 2005). Phage must be lytic and non-transducing as minimum requirements to ensure safety (Greer, 2005). Nevertheless, application of bacteriophages is a non-destructive, natural, self-perpetuating biocontrol method and can be as efficient as chemical agents for controlling specific bacterial pathogens (Leverentz et al., 2001). On the other hand, the high specificity of phages allows direct application onto a product or the possibility to use bacteriophages as "food additives," mixing them with foods without affecting their quality (Jay, 1996), hygiene and other normal microbiota viability of the food (Kudva et al., 1999) or the consumers' (Chibani-Chennoufi et al., 2004).

Previous studies have demonstrated the feasibility of isolating phages that specifically lyse O157:H7 E. coli strains (Sulakvelidze and Barrow, 2005; Raya et al., 2006). O'Flynn et al. (2004) developed a three-phage cocktail that was effective for reducing the numbers of E. coli $\mathrm{O} 157: \mathrm{H7}$ on meat products. On the other hand, in a similar experiment, Dykes and Moorehead (2002) found no effect of bacteriophage for control of Listeria monocytogenes development on contaminated beef, however, this treatment did not yield an appreciable reduction due to the low MOI used. Also, phage-mediated reductions of bacterial cell viability have been reported in various food matrices like contaminated melon (Leverentz et al., 2003) and cheese (Carlton et al., 2005; Bueno et al., 2012).

Phages isolated in this study were characterized by their host range, electron microscopy (DT1 and DT6), and PCR analysis. The host range evaluation demonstrated that all O157:H7 strains, most non-O157 STEC and some EPEC isolated from diarrheic faeces or food, were sensitive to one or several bacteriophages. In contrast, no nonpathogenic strain was affected. These finding suggest the possibility of using phages for food conservation without altering the gastrointestinal tract normal microbiota. However, a broader host range needs to be assessed to ensure safety for commensal bacteria. Phages did not contain genes encoding stx1, stx2, eaeA, $L T 1$ and $S T 1$, but other virulence factors and phage-encoded genes may contribute to bacterial virulence, so further sequencing and bioinformatic analysis are required to ensure they are benign prior to their use as biocontrol tools.

DT1 and DT6 on meat, gave statistically significant VC reductions, comparable to those previously reported (O'Flynn et al., 2004). EPEC920 was tested with both phages individually; at $5^{\circ} \mathrm{C}$ DT6 produces a minor reduction in VC count but a rapid and prolonged effect in time. This observation may be related to different adsorption rate and lysis time distinctively influenced by environmental conditions (Shao and Wang, 2008). Higher reductions were observed (for O157:H7 STEC) at the higher temperature $\left(24^{\circ} \mathrm{C}\right)$, probably due to the active growth of bacteria allowing an efficient bacteriophage replication. Similar results at 5 and $24^{\circ} \mathrm{C}$ for Salmonella and Campylobacter were described by Bigwood et al. (2008). The biocontrol effect for all phages analyzed was found to be dose-dependent, with the highest phage concentration being the most effective, as was also found by Leverentz et al. (2001). Our findings showed that phage-bacteria interaction on meat surfaces was significantly influenced by the initial number of inoculated phage and bacteria. Atterbury et al. (2003) obtained marginal reductions of approximately $1 \log$ CFU only with high initial bacterial density of $C$. jejuni (4-6 log CFU). The requirements for a relatively high threshold density 

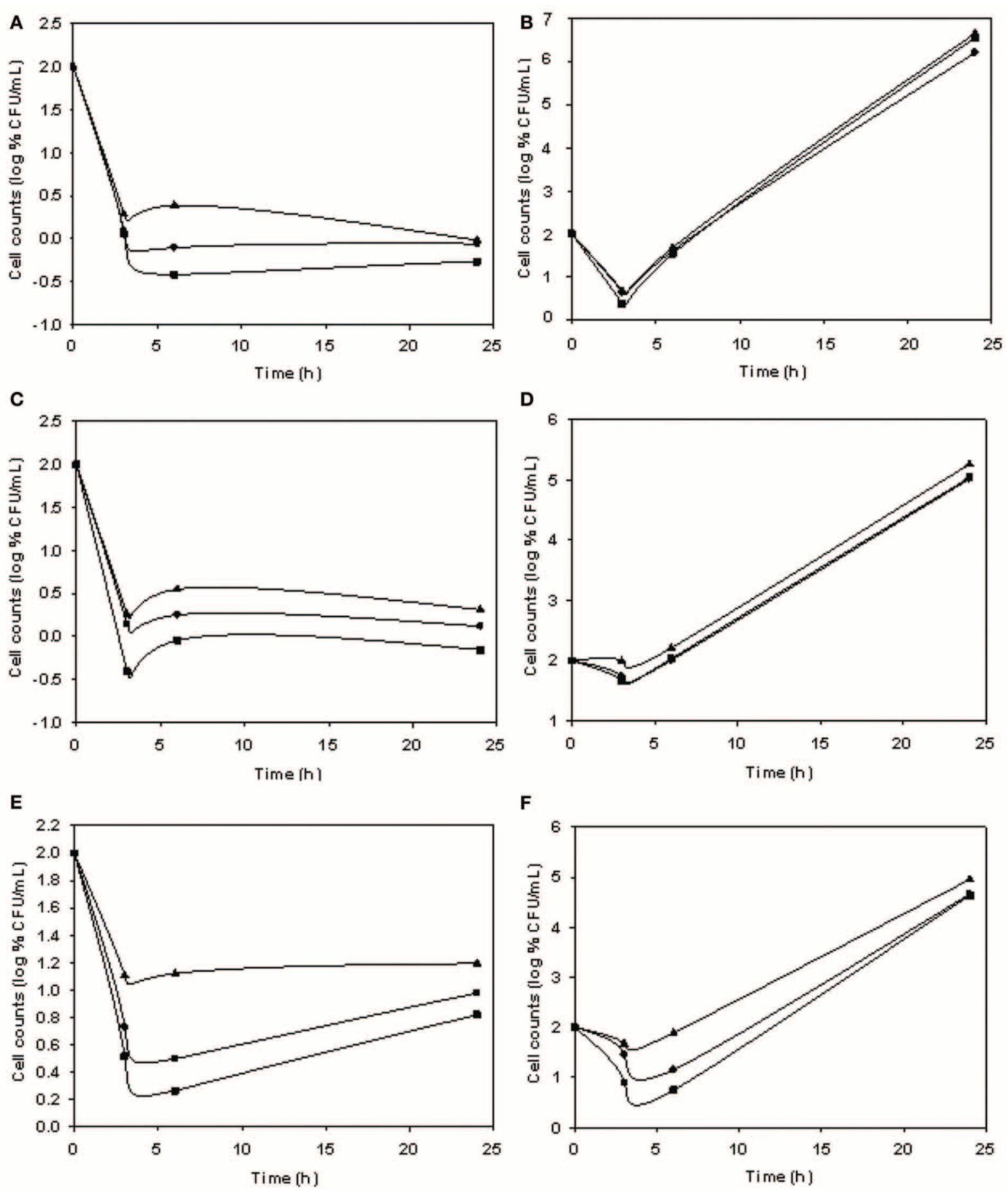

FIGURE 3 | Comparison of the Iytic ability of phages at different MOI and temperatures. Symbols represent phage free controls $(\mathbf{\Lambda})$, low $\mathrm{MOI}(\bullet)$, and high $\mathrm{MOI}(\mathbf{\square})$. Cell count $(\mathrm{CFU} / \mathrm{mL})$ using as matrix

inoculated meat with DT1/EPEC920 at $5^{\circ} \mathrm{C}$ (A) and $24^{\circ} \mathrm{C}$ (B), DT6/EPEC920 at $5^{\circ} \mathrm{C}$ (C) and $24^{\circ} \mathrm{C}$ (D) and DT6/O157:H7 STEC at $5^{\circ} \mathrm{C}$ (E) and $24^{\circ} \mathrm{C}(\mathrm{F})$

of bacterial host cells may limit the impact of phages on bacteria, constituting an important impediment to phage biocontrol (Greer, 2005). In addition, there are several factors influencing inactivation on food, the most relevant in our experiments is the food matrix ability to absorb liquid from the phage suspension. This is a decisive parameter which physically limits the distribution of phage particles in order to reach all targeted bacteria. Therefore, decreased effectiveness of these treatments 

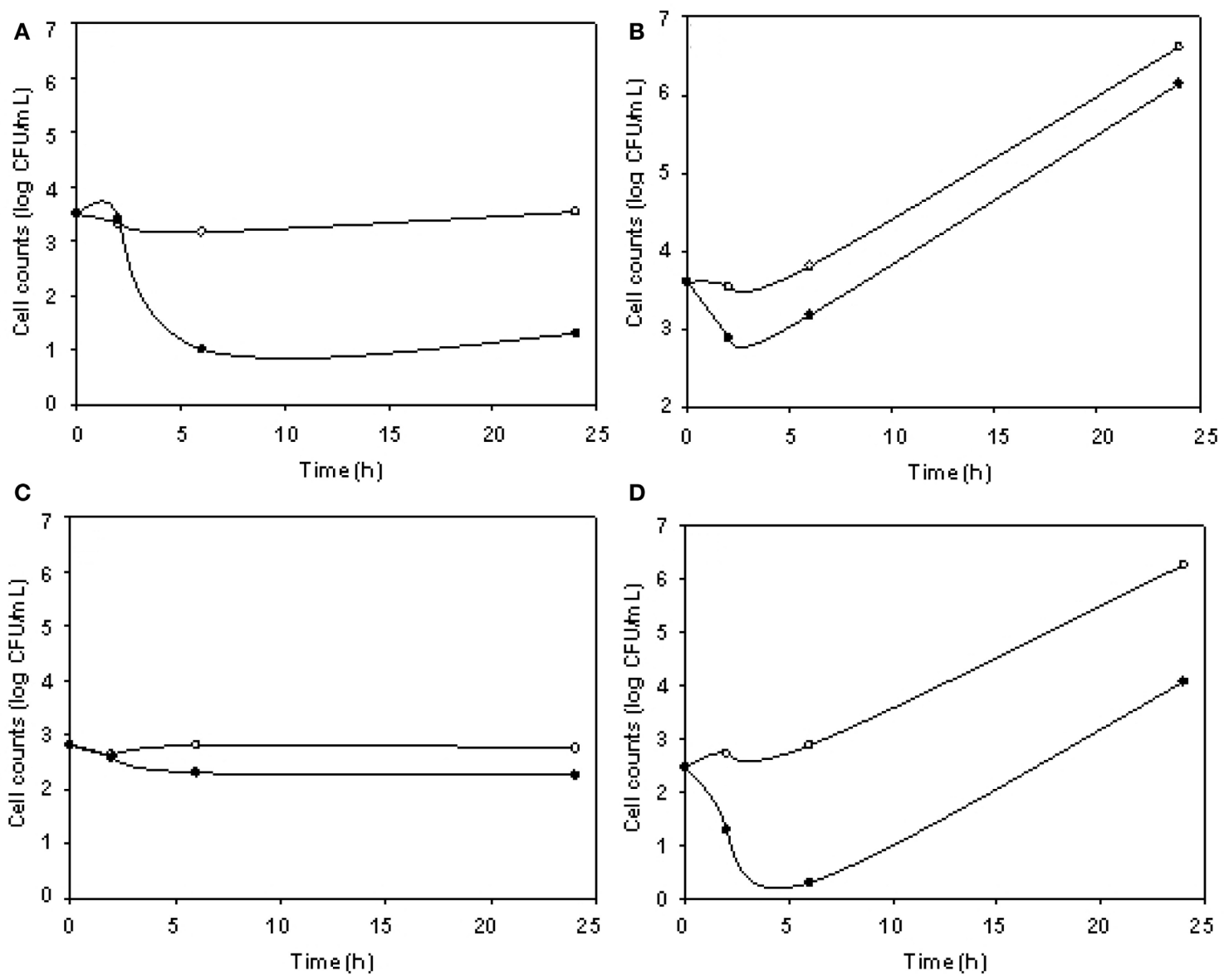

FIGURE 4 | E. coli viable cell counts (CFU/mL) in absence (०) and presence (•) of phages (cocktail) in meat products. Cocktail/DH5 $\alpha$ at $5^{\circ} \mathrm{C}(\mathrm{A})$, cocktail/DH5 $\alpha$ at $24^{\circ} \mathrm{C}$ (B), cocktail/O157:H7 STEC at $5^{\circ} \mathrm{C}$ (C), and cocktail/O157:H7 STEC at $24^{\circ} \mathrm{C}$ (D) systems.

Table 5 | In vitro and meat BIM isolation and determination of BIM frequency.

\begin{tabular}{llll}
\hline Source of BIMs & Presumptive BIMs tested & Confirmed BIMs $(\%)$ & BIM frequency (mean \pm SD) $^{\mathbf{a}}$ \\
\hline Secondary culture & 8 EPEC & $6(75.0)$ & EPEC/DT1 $=8.7 \times 10^{-7} \pm 3.9 \times 10^{-8}$ \\
& 8 O157:H7 & & EPEC/DT6 $=6.5 \times 10^{-7} \pm 4.8 \times 10^{-8}$ \\
Meat & STEC & $2(25.0)$ & O157:H7 STEC/DT1 $=1.8 \times 10^{-6} \pm 1.5 \times 10^{-7}$ \\
& & O157:H7 STEC/DT6 $=1.3 \times 10^{-6} \pm 9.4 \times 10^{-7}$
\end{tabular}

${ }^{a} S D$, standard deviation. Means and SD were calculated from duplicate experiments.

EPEC, enteropathogenic E. coli; 0157:H7 STEC: O157:H7 Shigatoxigenic E. coli.

may be partially due to limited diffusion and contact between bacteria and phage particles. Moreover, targeted bacteria may be embedded within the rather complex food matrix, thereby shielding them from phage particles. On these grounds, a greater biocontrol effect may be achieved by modifying phage application, e.g., by using larger liquid volumes to avoid total liquid absortion. While the results were statistically significant we cannot ascertain the practical use of these phages individually on meat products, mainly due to the $1.15 \log$ reduction obtained at best. However, the phage cocktail (containing DT1 and DT6) at a higher MOI was able of further reduce viable cell counts of
O157:H7 STEC (464) than individual phages. This indicates that phages may be of practical value if cocktails contain higher numbers of different phages (to reduce BIMs emergence and expand cocktail host range) and higher MOI values, since others authors report that working with higher phage concentrations generally resulted in greater inactivation (Guenther et al., 2009). In addition, $\mathrm{DH} 5 \alpha$ indicator strain was only significantly reduced at $5^{\circ} \mathrm{C}$, this reduction may be caused by lysis from without since $\mathrm{DH} 5 \alpha$ has a shorter lipopolysaccharide (LPS), thereby being more permissive and susceptible to this mechanism, while for O157:H7 STEC (464) at $5^{\circ} \mathrm{C}$ this mechanism was not observed and 
no reduction was obtained. This may rather be due to the absence of bacterial growth necessary for phage replication. At $24^{\circ} \mathrm{C}$, $\mathrm{DH} 5 \alpha$ cell number was not reduced (only after a $3 \mathrm{~h}$ of incubation a $0.66 \log$ reduction was observed) and re-growth was observed. This recovery in cell number may be due to cells escaping phage treatment by limited phage diffusion and a subsequent multiplication in addition to BIMs emergence.

In our trials we found an increase in VC number after $24 \mathrm{~h}$ at $24^{\circ} \mathrm{C}$, suggesting that there is a potential phage-resistant variant selection under these testing conditions. Thus, we propose to analyze the existence of spontaneous bacteriophage-insensitive mutants (BIMs), naturally present in bacteria, in order to evaluate if they could prevent the use of phages to improve food safety. Other authors have also reported a subsequent bacterial growth during the in vitro challenge test (O'Flynn et al., 2004). BIMs emergence, which could compromise the efficacy of a phage treatment, is often associated with point mutations in genes encoding receptor molecules on the bacterial cell surface and commonly revert to phage sensitivity rapidly (Garcia et al., 2007). Kudva et al. (1999) propose that low temperatures and absence of bacterial growth favor phage adsorption and infection. In contrast, higher temperatures, cell growth, and the potential for phenotypic variability in expression of the $\mathrm{O}$-antigen favor survival of phage-resistant cells. We were able to isolate E. coli BIMs from meat assays and, at a higher rate, when using the secondary culture method. BIMs isolated in this study were tested to evaluate resistance phenotype stability and reversion. As previously reported for other systems (O'Flynn et al.,

\section{REFERENCES}

Abuladze, T., Li, M., Menetrez, M. Y., Dean, T., Senecal, A., and Sulakvelidze, A. (2008). Bacteriophages reduce experimental contamination of hard surfaces, tomato, spinach, broccoli, and ground beef by Escherichia coli O157:H7. Appl. Environ. Microbiol. 74, 6230-6238. doi: 10.1128/AEM.01465-08

Atterbury, R. J., Connerton, P. L., Dodd, C. E., Rees, C. E., and Connerton, I. F. (2003). Application of host-specific bacteriophages to the surface of chicken skin leads to a reduction in recovery of Campylobacter jejuni. Appl. Environ. Microbiol. 69, 6302-6306. doi: 10.1128/AEM.69.10.63026306.2003

Balagué, C., Khan, A., Fernandez, L., Redolfi, A., Aquili, A., Voltattorni, P., et al. (2006). Occurrence of non-O157 shiga toxin-producing Escherichia coli in ready-to-eat food from supermarkets in Argentina. Food Microbiol. 23, 307-313. doi: 10.1016/j.fm.2005.03.005

Balagué, C., Silva de Ruiz, C., Rey, R., Evangelista de Duffard, A. M., and Nader-Macías, M. E. (2004). Clofibric and ethacrynic
2004), all these BIMs present low emergence frequency, variable stability, and reversion, namely, mutants resistant to phage DT6 revert while those resistant to DT1 show no reversion to phage sensitivity. These findings suggest that E. coli BIMs should not prevent the use of phages as biocontrol tools, mainly due to the low emergence frequency observed for all phages evaluated. In our trials phage cocktail reduced the appearance of presumptive-BIMs, however, further studies are required in order to evaluate the optimal conditions allowing the reduction of BIM emergence such as adding more different phages in the cocktail mixture.

We have isolated 10 bacteriophages belonging to the T-even type of the Myoviridae family. Phages isolated in this study were negative for all the virulence factors assayed and presented lytic activity for different $E$. coli virotypes. In addition, all nonpathogenic strains evaluated were not affected. BIMs isolated by exposure to DT1 and DT6 showed low emergence frequency and in in vitro challenge tests VC reductions were highly significant (up to 6.3 log units) (data not shown). However, on pieces of beef assayed, reduction obtained with individual phages was low and the phage cocktail showed greater reductions although lower than expected.

\section{ACKNOWLEDGMENTS}

We want to thank Tomas Subils, Guillermo Ebner, and Cecilia Casabonne for their assistance. We also thank M. Culasso, M. Robson, M. De Sanctis, and G. Raimundo for their helpful suggestions. acids prevent experimental pyelonephritis by Escherichia coli in mice. FEMS Immunol. Med. Microbiol. 42, 313-319. doi: 10.1016/j.femsim.2004.06.026

Bettelheim, K. A. (2007). The non-O157 Shiga-toxigenic (Verocytotoxigenic) Escherichia coli; under-rated pathogens. Crit. Rev. Microbiol. 33, 67-87. doi: 10.1080/10408410601172172

Bigwood, T., Hudson, J. A., Billington, C., Carey-Smith, G. V., and Heinemann, J. A. (2008). Phage inactivation of foodborne pathogens on cooked and raw meat. Food Microbiol. 25, 400-406. doi: 10.1016/j.fm.2007.11.003

Binsztein, N., Picandet, A., Notario, R., Patrito, E., De Lesa, M., De Petris, A., et al. (1999). Antimicrobial resistance among species of Salmonella, Shigella, Escherichia, and Aeromonas isolated from children with diarrhea in 7 Argentinian centers. Rev. Latinoam. Microbiol. 41, 121-126.

Bueno, E., Garcia, P., Martínez, B., and Rodríguez, A. (2012). Phage inactivation of Staphylococcus aureus in fresh and hard-type cheeses. Int. J. Food Microbiol. 158, 23-27. doi: 10.1016/j.ijfoodmicro.2012.06.012
Bolondi, A., Gaggino, O., and Monesiglio, J. (1995). Electronic Microscopy: General Techniques. Electronic Microscopy Unit and Applied Biochemistry of the Research Centre in Veterinary Sciences. Castelar, INTA.

Breitbart, M., Hewson, I., Felts, B., Mahaffy, J. M., Nulton, J., Salamon, P., et al. (2003). Metagenomic analyses of an uncultured viral community from human feces. J. Bacteriol. 185, 6220-6223. doi: 10.1128/JB.185 20.6220-6223.2003

Brooks, J. T., Sowers, E. G., Wells, J. G., Greene, K. D., Griffin, P. M., Hoekstra, R. M., et al. (2005). Non-O157 Shiga toxin-producing Escherichia coli infections in the United States, 1983-2002. J. Infect. Dis. 192, 1422-1429. doi: 10.1086/ 466536

Carlton, R. M., Noordman, W. H., Biswas, B., de Meester, E. D., and Loessner, M. J. (2005). Bacteriophage P100 for control of Listeria monocytogenes in foods: genome sequence, bioinformatic analyses, oral toxicity study, and application. Regul. Toxicol. Pharmacol. 43, 301-312. doi: 10. 1016/j.yrtph.2005.08.005
Chibani-Chennoufi, S., Sidoti, J., Bruttin, A., Kutter, E., Sarker, S., and Brüssow, H. (2004). In vitro and in vivo bacteriolytic activities of Escherichia coli phages: implications for phage therapy. Antimicrob. Agents Chemother. 48, 2558-2569. doi: 10.1128/AAC.48.7.2558-2569. 2004

Clark, J. R., and March, J. B. (2006). Bacteriophages and biotechnology: vaccines, gene therapy and antibacterials. Trends Biotechnol. 24, 212-218. doi: 10.1016/j.tibtech.2006.03.003

Dykes, G. A., and Moorhead, S. M. (2002). Combined antimicrobial affect of nisin and a listeriophage against Listeria monocytogenes in broth but not in buffer or on raw beef. Int. J. Food Microbiol. 73, 71-81. doi: 10.1016/S0168-1605(01)00710-3

FDA. (2006). Food additives permitted for direct addition to food for human consumption; bacteriophage preparation. Fed. Regist. 71, 47729-47732.

Fernandez, D., Rodriguez, E. M., Arroyo, G. H., Padola, N. L., and Parma, A. E. (2009). Seasonal variation of Shiga toxin-encoding genes (stx) and detection of E. coli $\mathrm{O} 157$ in 
dairy cattle from Argentina. J. Appl. Microbiol. 106, 1260-1267. doi: 10.1111/j.1365-2672.2008.04088.x

Frankel, G., Phillips, A. D., Rosenshine, I., Dougan, G., Kaper, J. B., and Knutton, S. (1998). Enteropathogenic and enterohaemorrhagic Escherichia coli: more subversive elements. Mol. Microbiol. 30, 911-921. doi: 10.1046/j.13652958.1998.01144.x

Garcia, P., Madera, C., Martinez, B., and Rodriguez, A. (2007). Biocontrol of Staphylococcus aureus in curd manufacturing processes using bacteriophages. Int. Dairy J. 17, 1232-1239. doi: 10.1016/j. idairyj.2007.03.014

Goodridge, L., Gallaccio, A., and Griffiths, M. (2003). Morphological, host range, and genetic characterization of two coliphages. Appl. Environ. Microbiol. 69, 5364-5371. doi: 10.1128/AEM. 69.9.5364-5371.2003

Greer, G. (2005). Bacteriophage control of foodborne bacteria. J. Food Prot. $68,1102-1111$.

Griffin, P. M., Mead, P. S., and Sivapalasingam, S. (2002). "Escherichia coli O157:H7 and other enterohemorrhagic Escherichia coli," in Infections of the Gastrointestinal Tract (2nd Edn.) eds M. J. Blaser, P. D. Smith, J. I. Ravdin, H. B. Greenberg, and R. L. Guerrant (Philadelphia, PA: Lippincott Williams and Wilkins), 627-642.

Guenther, S., Huwyler, D., Richard, S., and Loessner, M. J. (2009). Virulent bacteriophage for efficient biocontrol of Listeria monocytogenes in ready-to-eat foods. Appl. Environ. Microbiol. 75, 93-100. doi: 10.1128/AEM.01711-08

Guglielmotti, D., Briggiler Marcó, M., Golowczyc, M., Reinheimer, J., and Quiberoni, A. (2007). Probiotic potential of Lactobacillus delbrueckii strains and their phage resistant mutants. Int. Dairy J. 17, 916-925. doi: 10.1016/j.idairyj. 2006.11.004

Hitch, G., Pratten, J., and Taylor, P. W. (2004). Isolation of bacteriophages from the oral cavity. Lett. Appl. Microbiol. 39, 215-219. doi: 10.1111/j.1472-765X.2004.01565.x

Holck, A., and Berg, J. (2009). Inhibition of Listeria monocytogenes in cooked ham by virulent bacteriophages and protective cultures. Appl. Environ.
Microbiol. 75, 6944-6946. doi: 10.1128/AEM.00926-09

Jamalludeen, N., Jonson, R. P., Friendship, R., Kropinski, A. M., Lingohr, E. J., and Gyles, C. L. (2007). Isolation and characterization of nine bacteriophages that lyse O149 enterotoxigenic Escherichia coli. Vet. Microbiol. 124, 47-57. doi: 10.1016/j.vetmic.2007. 03.028

Jay, J. M. (1996). Microorganism in fresh ground meats: the relative safety of products with low versus high numbers. Meat Sci. 43, S59-S66. doi: 10.1016/0309-1740 (96)00055-1

Jenkins, C., Pearce, M. C., Smith, A. W., Knight, H., Shaw, I. D. J., Cheasty, T., et al. (2003). Detection of Escherichia coli serogroups O26, O103, O111 and O145 from bovine faeces using immunomagnetic separation and PCR/DNA probe techniques. Lett. Appl. Microbiol. 37, 207-212. doi: 10.1046/j.1472-765X.2003.01379.x

Kennedy, J. E. J., and Bitton, G. (1987). "Bacteriophages in foods," in Phage Ecology, eds S. M. Goyal, C. P. Gerba, G. Bitton (New York, NY: John Wiley and Sons), 289-316.

Kudva, I. T., Jelacic, S., Tarr, P. I., Youderian, P., and Hovde, C. J. (1999). Biocontrol of Escherichia coli $\mathrm{O} 157$ with O157-specific bacteriophages. Appl. Environ. Microbiol. 65, 3767-3773.

Leverentz, B., Conway, W. S., Alavidze, Z., Janisiewicz, W. J., Fuchs, Y., Camp, M. J., et al. (2001). Examination of bacteriophage as a biocontrol method for Salmonella on fresh-cut fruit: a model study. J. Food Prot. 64, 1116-1121.

Leverentz, B., Conway, W. S., Camp, M. J., Janisiewicz, W. J., Abuladze, T., Yang, M., et al. (2003). Biocontrol of Listeria monocytogenes on fresh-cut produce by treatment with lytic bacteriophages and a bacteriocin. Appl. Environ. Microbiol. 69, 4519-4526. doi: 10.1128/AEM.69.8.4519-4526.2003

NCASP (Nephrology Committee of the Argentinian Society of Pedriatics). (1995). Hemolytic uremic syndrome (HUS) incidence in Argentinian Republic. Arch. Arg. Pediat. 93, 409-411.

O’Flynn, G., Ross, R. P., Fitzgerald, G. F., and Coffey, A. (2004). Evaluation of a cocktail of three bacteriophages for biocontrol of Escherichia coli O157:H7. Appl. Environ. Microbiol. 70, 3417-3424. doi: 10.1128/AEM.70.6.3417-3424.2004

Ogura, Y., Ooka, T., Whale, A., Garmendia, J., Beutin, L., Tennant, S., et al. (2007). TccP2 of O157:H7 and non-O157 Enterohemorrhagic Escherichia coli (EHEC): challenging the dogma of EHEC-induced actin polymerization. Infect. Immun. 75, 604-612. doi: 10.1128/IAI. 01491-06

Pass, M. A., Odedra, R., and Batt, R. M. (2000). Multiplex PCRs for identification of Escherichia coli virulence genes. J. Clin. Microbiol. 38, 2001-2004.

Raya, R., Varey, P., Oot, R., Dyen, M., Callaway, T., Edrington, T., et al. (2006). Isolation and characterization of a new T-Even bacteriophage, CEV1, and determination of its potential to reduce E. coli O157:H7 levels in sheep. Appl. Environ. Microbiol. 72, 6405-6410. doi: 10.1128/AEM 03011-05

Ritchie, J. M., Wagner, P. L., Acheson, D. W. K., and Waldor, M. K. (2003). Comparison of Shiga toxin production by hemolytic-uremic syndrome-associated and bovineassociated Shiga toxin-producing Escherichia coli isolates. Appl. Environ. Microbiol. 69, 1059-1066. doi: 10.1128/AEM.69.2.1059-1066. 2003

Rivas, M., Miliwebsky, E., Chinen, I., Deza, N., and Leotta, G. A. (2006). Epidemiology of hemolytic uremic syndrome in Argentina. Etiologic agent diagnosis, reservoirs and routes of transmission. Medicina 66, 27-32.

Rivas, M., Sosa-Estani, S., Rangel, J., Caletti, M. G., Vallés, P., Roldán, C. D., et al. (2008). Risk factors for sporadic Shiga toxin-producing Escherichia coli infections in children, Argentina. Emerg. Infect. Dis. 14, 763-771. doi: 10.3201/eid1405 071050

Shao, Y., and Wang, I. N. (2008). Bacteriophage adsorption rate and optimal lysis time. Genetics 180 471-482. doi: 10.1534/genetics.108. 090100

Su, C., and Brandt, L. J. (1995). Escherichia coli O157:H7 infection in humans. Ann. Int. Med. 123,
698-714. doi: 10.7326/0003-4819123-9-199511010-00009

Sulakvelidze, A. (2011). The challenges of bacteriophage therapy. Eur. Ind. Pharm. 10, 14-18.

Sulakvelidze, A., and Barrow, P. (2005). "Phage therapy in animals and agribusiness," in Bacteriophages: Biology and Applications, eds E. Kutter and A. Sulakvelidze (Boca Raton, FL: CRC Press), 335-380.

Summers, W. C. (1999). Félix d'Hérelle and the Origins of Molecular Biology. New Haven, CT: Yale University Press.

Thorpe, C. M., Ritchie, J. M., and Acheson, D. W. K. (2002). "Enterohemorrhagic and other Shiga toxin-producing Escherichia coli," in Escherichia coli: Virulence Mechanisms of a Versatile Pathogen, ed M. Donnenberg (Boston, MA: Academic Press), 119-154.

Tozzi, A. E., Caprioli, A., Minelli, F., Gianviti, A., De Petris, L., Edefonti, A., et al. (2003). Shiga toxinproducing Escherichia coli infections associated with hemolytic uremic syndrome, Italy, 1988-2000. Emerg. Infect. Dis. 9, 106-108. doi: 10.3201/eid0901.020266

Yoon, J. W., and Hovde, C. J. (2008). All blood, no stool: enterohemorrhagic Escherichia coli O157:H7 infection. J. Vet. Sci. 9, 219-231.

Conflict of Interest Statement: The authors declare that the research was conducted in the absence of any commercial or financial relationships that could be construed as a potential conflict of interest.

Received: 06 December 2012; accepted: 22 May 2013; published online: 06 June 2013.

Citation: Tomat D, Migliore L, Aquili V, Quiberoni A and Balagué C (2013) Phage biocontrol of enteropathogenic and shiga toxin-producing Escherichia coli in meat products. Front. Cell. Infect. Microbiol. 3:20. doi: 10.3389/ fcimb.2013.00020

Copyright (C) 2013 Tomat, Migliore, Aquili, Quiberoni and Balagué. This is an open-access article distributed under the terms of the Creative Commons Attribution License, which permits use, distribution and reproduction in other forums, provided the original authors and source are credited and subject to any copyright notices concerning any thirdparty graphics etc. 